\title{
A Fuzzy Algorithm for understanding the customer's desire. An application designed for textile industry.
}

\author{
Fabio Krykhtine \\ Federal University of Rio de Janeiro - PEP/COPPE/UFRJ - Brazil \\ E-mail: fabiokrykhtine@yahoo.com \\ Carlos Alberto Nunes Cosenza \\ Federal University of Rio de Janeiro - PEP/COPPE/UFRJ - Brazil \\ E-mail: cosenza@pep.ufrj.br \\ Francisco Antônio Dória \\ Federal University of Rio de Janeiro - PEP/COPPE/UFRJ - Brazil \\ E-mail: fadoria63@gmail.com \\ Submission: $23 / 04 / 2013$ \\ Accept: 05/05/2013
}

\section{ABSTRACT}

The paper aims at showing how a textile industry can select from a mix of products, the best products to be produced by using the customer's point of view. The Fuzzy Algorithm for fashion industry is a tool developed to optimize the production and reduce losses and storage costs in the textile industry environment. As the textile industry has an expressive position as an employment intensive industry around the world, its health can be perceived by the ability of their managers in restricting the production to low costs limits, thus acquiring better sales and value to the products. The supply chain management must apply innovations and tools that can deal with these paradigms with dexterity. In a global source operation, the information that one product will be very well accepted by a group of customers with a given price is very welcome. In a sustainability scenario, the algorithm can promote savings in many factors such as: labour, electric energy, water and many other resources spent by the textile industries that have significant impact in economy and environment. Finally, this paper shows a different view to understand the customer's desire through linguistic variable processed in a Fuzzy Logic algorithm. The tool yields an index to the product and find out in a mix of products, which of them will be better accepted by the final customer. 
DOI: 10.14807/ijmp.v4i1.75

Keywords: Fuzzy Logic, Textile Industry, Production Optimization.

\section{FASHION BUSINESS DYNAMICS}

The fashion segment in Brazil is represented by many medium-size and small industries which employ 1,7 million people as manpower. These industries, according to $A B I T$ more than 30 thousand, present their fashion collections in fairs and other events. Throughout many months, designers develop products based on international tendencies and research, in which the main goal is to create a new season collection. This mix is composed based on a suggested theme created in a brand identity conception that leads to customer's selection.

The most important events in the fashion industry are fairs. A fair is a place where the wholesale buyers select products from many brands and places their orders. One Brand is supported by many other enterprises from the textile segment which provide the main brand with different kinds of services and raw material in a supply chain operation.

At the end of these events, many products will have been selected in client's orders. These products will compose the shop window in the next season. The production starts in the plant based on current sales and sales projections.

For the next 45 days the sales representatives take up sales from their offices and showrooms. They will collect orders and send them to the manufactures.

In 60 days, a first group of product is delivered. During the next two months other deliveries will complete the orders.

In the manufactures, by the end of the event, the production manager will unify a complete list of orders. From a complete collection, $25 \%$ of products must immediately be manufactured based on a bet. This bet is a judgment made by designers and production managers that cross sales projection to define a lot size that must be produced.

The bet is necessary to make the delivery possible for some product, 15 days after the orders have been emitted by sales representative.

Owing to the fact that the minimum lot must be respected (SLACK, 1997), many products will not be manufactured according to the sales results. 
INDEPENDENT JOURNAL OF MANAGEMENT \& PRODUCTION (IJM\&P)

http://www.ijmp.jor.br

v. 4, n. 1, January - June 2013.

ISSN: 2236-269X

DOI: 10.14807/iimp.v4i1.75

The production managers expect that the projection of sales, that rules the production of $25 \%$ of the clothes collection, become real, otherwise the products will increase stocks.

The storage increase is a problem to be solved in many industrial segments, especially in the fashion industry where the season's change brings obsolescence to the product mix. When the season finishes, the product sales value will decrease, increasing financial losses.

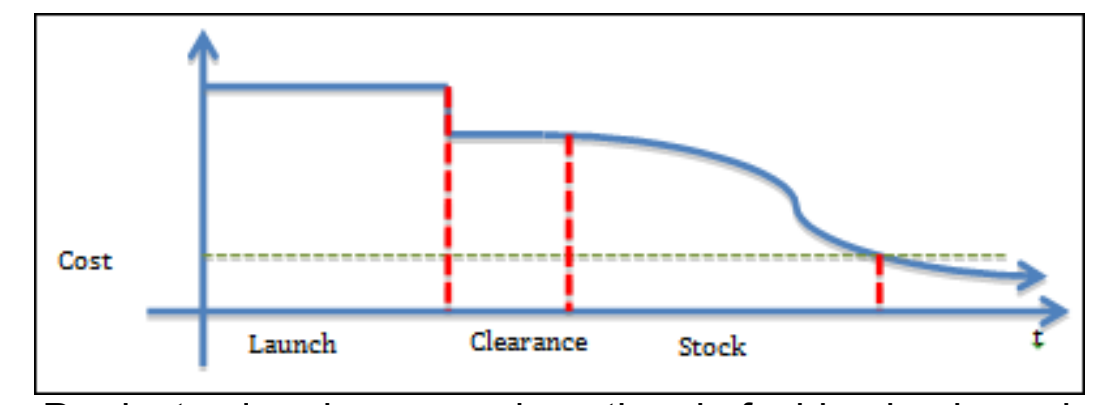

Fig. 1 - Product value decrease along time in fashion business industry. Source: LODE, 2011.

\section{THE MOTIVATION TO CREATE A DECISION MAKING TOOL}

This case study started as a contribution to help managers to make a better bet. The storage increase is a problem that hinders the profit results and is the reason why many firms have doors closed.

While the designers think that the business is, basically, to create clothes collections, production managers have the challenge to optimize the supply chain and sales to turn investment into profits, the main core business. The fashion industries would not be a reality without the professional management approach and many other tools that support it.

The desire algorithm was developed to solve the problem of storage increase in fashion industries but the research has shown the algorithm's potential in applications to other industries. It can measure the customer's attractiveness to any product, it can also define priority markets in launches and prices policies by ranking fuzzy numbers maximizing and minimizing sets (CHEN, 1985).

The main objective is to maximize premium-selling price from manufacture and reduce the stock levels. The price markup represents the value achieved for a monetary unit invested in a product. The value decreases along the time until it achieves a stock value, as seen below in the markup table: 
INDEPENDENT JOURNAL OF MANAGEMENT \& PRODUCTION (IJM\&P)

http://www.ijmp.jor.br

v. 4, n. 1, January - June 2013.

ISSN: 2236-269X

DOI: 10.14807/iimp.v4i1.75

Table 1 - The Markup common in the fashion business industries.

\begin{tabular}{lrrr}
\hline PRICE & PREMIUM & CLEARANCE & STORAGE \\
\hline MARKUP & 2,5 & 1,8 & 0,8 \\
\hline PRODUCTION COST $(\$ 100)$ & $\$ 250$ & $\$ 180$ & $\$ 80$ \\
\hline PROFIT/ LOSSES & $\$ 150$ & $\$ 80$ & $-\$ 20$ \\
\hline
\end{tabular}

\section{WHY THE USE OF FUZZY LOGIC IS INDICATED?}

Lotfi Zadeh presented fuzzy logic to the world in 1965. In his first article, Zadeh exposed a method to represent the human reasoning in a mathematical concept. The fuzzy sets applications can be found everywhere in the contemporaneous world, especially in sophisticated electronic gadgets. The fuzzy logic application development is connected to many decision methods (HASS; MEIXNER, 2002), industrial location, electronic controls, etc.

About fuzzy logic applications, Terano (1992) says: "The outstanding feature of fuzzy sets is the ability to express the amount of ambiguity in human thinking and subjectivity (including natural language) in a comparatively undistorted manner."

The fuzzy logic was selected to this work because it is a typical case of imprecision (ROSS, 2010). The facts that compose the value perception by customers are the first attributes that must be identified. These facts must be translated in criteria and a group of linguistic expressions.

During the researches, the fuzzy logic was used to build a model that could select in a collection, which of the products would have commercial success. Other models for selection and decision based on fuzzy logic have been very successful in locational studies (COSENZA, 1981), site selection (NARASIMHAN, 1979) and in ranking decisions using multi-criteria (LIANG; WANG, 1991).

The conception using fuzzy logic gave us the freedom to deal with ambiguity and imprecision (ROSS, 2010), common in fashion business environment, in a product evaluation and obtain as a result some secure information to direct manager decisions.

\section{POTENTIAL OPPORTUNITIES}

When this work started, the main claim was to create an algorithm that could preview the costumer desire as a solution to a problem in the textile industry, more specifically in clothes production ruled by the fashion calendar and tendency. 
INDEPENDENT JOURNAL OF MANAGEMENT \& PRODUCTION (IJM\&P)

http://www.ijmp.jor.br

v. 4, n. 1, January - June 2013.

ISSN: 2236-269X

DOI: 10.14807/iimp.v4i1.75

Understanding the demand for products in fashion industry is very difficult (ABRANCHES, 1990). In fact, it is a judgment made by experienced professionals that capture the fashion tendencies or, by the use of intense marketing and advertising budget, they turn it real (CHURCHILL, 2000).

While a fashion tendency is created by big brands and budgets, another group, composed by small and medium size manufactures, maintains their brands observing the whole market.

The fashion designers usually work in research for tendencies and in new products development based on research on other collections, redesigning successful products.

As problems, the tendencies changes every season, new materials and techniques are developed and the final products have a short life cycle (PORTER, 2004) where the main value is depreciated in few months.

A research in fashion business tendency could minimize the deflection from the main tendency, but the diversity and creativity make the industry rich by the value perception in original product ideas. That is innovation (KOTLER, 2005).

So, what should be the methodology to create original products and launch them in the market with success?

In fact, this work does not answer this question but helps the brands understand what product should be definitively excluded from a collection and which of them should receive more attention in a bet based production. Moreover, it can help managers to minimize the quantity of product in storage by adjusting price rules based on value perception by customers group (BLACKWELL, 2005).

By the use of a GIS tool and a regional research, using the desire algorithm, the brands can establish a regional sequence to launch their products and the price levels that will be well received by the market. Minimize losses and offer valued products to the market, in a scenario that investments are maximized, are the basic premise (SLACK, 1997). The challenge to plan a large-scale production in a segment where the historic information does not exist is too big.

How do we preserve a short industry from a competitive disadvantage (PORTER, 2004) configured by high levels in storage? 
INDEPENDENT JOURNAL OF MANAGEMENT \& PRODUCTION (IJM\&P)

http://www.ijmp.jor.br

v. 4, n. 1, January - June 2013.

ISSN: 2236-269X

DOI: 10.14807/iimp.v4i1.75

The Desire's algorithm provides a tool to analyze value to goods in many industrial segments and helps product launches and distribution rules. In the actual phase it can help as a research tool to test value perception of many goods in markets. It can also be applied in different ranges of regional areas where the product value is considered higher than others. At this point, the distribution of goods in a large-scale production and price's policies can be solved by maximum profits.

The textile industry in Brazil, has billed over $\$ 60$ billion per year since 2010 , according to ABIT. If in a small factory the model has succeeded in determining the best mix to be produced, in a large-scale production (CLEMENTE, 2008), the desire's model could achieve good results, dividing markets in regional customers and obtaining the best profits from each potential group.

Especially in Brazil, where the country size makes change in the cultural diversity from region to region (DORIA, 1999), the budget spent in commercial operation, advertising and logistic factors can be maximized.

A profit can be obtained in a logistic operation where the products are delivered first where it achieves a higher value perception. Of course it should be used together with other tools such as: GIS, ERP systems in which all operational information are computed.

As the customer accepts the products, achieving an equivalent value and sales results are consequence. This is why the algorithm is called Desire's Algorithm, because it measures value perception (CHURCHILL, 2000) from the customer in a price and its attractiveness. The industry, in this context, gains a different tool to provide researches before launching a new product or a new model.

In a direction for sustainability, followed globally, tools and models that reduce the impacts on the environment are absolutely welcome.

The cotton production uses much water, electric energy and manpower. From the raw material to the end product, the industrial process causes many environmental impacts. If the environmental cost is added, the problem grows. It represents a loss that should be accounted (CLEMENTE, 1998).

When the raw material usage is maximized in a succeeded production, which entire lot is sold in a better price, the environmental resources consumed are well 
INDEPENDENT JOURNAL OF MANAGEMENT \& PRODUCTION (IJM\&P)

http://www.ijmp.jor.br

v. 4, n. 1, January - June 2013.

ISSN: 2236-269X

DOI: 10.14807/iimp.v4i1.75

applied. Once textile industry uses caustic soda, sulphur and other waste, maximizing resources is absolutely important in a sustainability world panorama.

\section{THE METHODOLOGY}

To build an algorithm to the textile industry it is absolutely necessary to have an interaction with many professionals in the fashion business environment.

A group of interviews was done in a medium size factory with designers, production managers, buyers, sales representatives, photographers, fashion producers and customers.

The main group of criteria was pointed by these professionals and adapted to the linguistic expressions used in the fashion segment.

Five criteria are used in desire algorithm. In this case, the criteria are: desirability, colour, price, versatility and modeling. These criteria were considered important drivers of buying decision-making.

The criteria are balanced by the use of the modifiers: moderate important, important and very important.

To complete the algorithm, the appraiser is considered in the product evaluation. This fact is relevant because different professionals have distinct interaction with the conception and commercialization of the product.

The algorithm of desire, in the final conception, is a decision-making tool that helps managers to decide which product must be manufactured and receive more attention in a typical bet. Minimizing the bet error represents reducing investment in bad product and maximizing investment in a product well evaluated.

Finally, the model presented in this work will show how the main index is created, the ranking of decisions with four outputs and simulation of expected returns. The appraiser opinion will not be computed although it is a very simple mathematical operation. It would increase the index from 576 to 4032 options of possible results. 


\section{THE DESIRE'S ALGORITHM}

The algorithm modeled for fashion business segment, in the textile industry, was developed and applied in a cooperative work with professionals in a small factory, which guides the case study.

The style department, represented by designers, had discussed about the main factors that customers would consider to select a group of products in their orders, from a mix of 400 products.

The model was created to analyze many products in a collection and present to managers information about the attractiveness between products and customers, considering a determined price in a determined place (BLACKWELL, 2005).

Fuzzy logic comprehension is absolutely necessary to build the model. The experience to turn linguistic expression in value, in this case, fuzzy numbers that represent a region of values is the main point to obtain results from the imprecise information (ROSS, 2010).

It is based in 5 criteria for basic evaluation of the attractiveness power for a determinate product: desirability, color, price, modeling and versatility.

The criteria are influenced by modifiers which give the criteria an extra weight: very important, important and moderately important. Each criteria has its own parameters represented by linguistic variables translated in fuzzy sets.

The desire's algorithm considers different kinds of professional as appraisers and the mathematical model understands these opinions with different weights through the fuzzy sets. The appraisers listed to this model were: internal designers, external designers, fashion producers, sales manager, visitor, customers and sales representatives.

Basically, criteria, modifiers, and appraisers compose the mathematical model. The fuzzy sets are presented in the following table: 
INDEPENDENT JOURNAL OF MANAGEMENT \& PRODUCTION (IJM\&P)

http://www.ijmp.jor.br

v. 4, n. 1, January - June 2013.

ISSN: 2236-269X

DOI: 10.14807/iimp.v4i1.75

Table 2 - Five criteria represented by fuzzy sets used in the Desire's Algorithm.

\begin{tabular}{|c|c|c|c|c|}
\hline \multicolumn{5}{|c|}{ CRITERIAS } \\
\hline $\begin{array}{c}\text { C1 - } \\
\text { Desirability }\end{array}$ & C2 - Color & C3 - Price & $\begin{array}{c}\text { C4 - } \\
\text { Versatility }\end{array}$ & C5 - Modeling \\
\hline $\begin{array}{l}\text { Unwanted } \\
(0,0,3,4)\end{array}$ & $\begin{array}{l}\text { Don't Like } \\
(0,1,2,3)\end{array}$ & $\begin{array}{c}\text { Cheap } \\
(8,9,10,10)\end{array}$ & $\begin{array}{c}\text { Versatile Bit } \\
(1,2,2,3)\end{array}$ & $\begin{array}{c}\text { Do Not Dress } \\
\text { Well } \\
(1,2,2,3)\end{array}$ \\
\hline $\begin{array}{l}\text { Indifferent } \\
(2,3,4,5)\end{array}$ & $\begin{array}{l}\text { Indifferent } \\
(3,4,5,6)\end{array}$ & $\begin{array}{c}\text { Coherent } \\
(5,6,7,8)\end{array}$ & $\begin{array}{c}\text { Versatile } \\
(5,6,7,8)\end{array}$ & $\begin{array}{c}\text { Dresses Well } \\
(5,6,7,8)\end{array}$ \\
\hline $\begin{array}{c}\text { Desirable } \\
(5,6,7,8)\end{array}$ & $\begin{array}{c}\text { Like } \\
(5,6,8,9)\end{array}$ & $\begin{array}{l}\text { Expensive } \\
(3,4,5,6)\end{array}$ & $\begin{array}{c}\text { Very Versatile } \\
(7,8,10,10)\end{array}$ & $\begin{array}{c}\text { Dress Perfectly } \\
(7,8,10,10)\end{array}$ \\
\hline $\begin{array}{c}\text { Very Desirable } \\
(7,8,10,10)\end{array}$ & $\begin{array}{c}\text { Much Like } \\
(8,9,10,10)\end{array}$ & $\begin{array}{c}\text { Very } \\
\text { Expensive } \\
(0,1,2,3)\end{array}$ & & \\
\hline
\end{tabular}

Table 3 - Fuzzy Sets for criteria used in the Desire's Algorithm.

\section{FUZZY SETS FOR CRITERIAS}

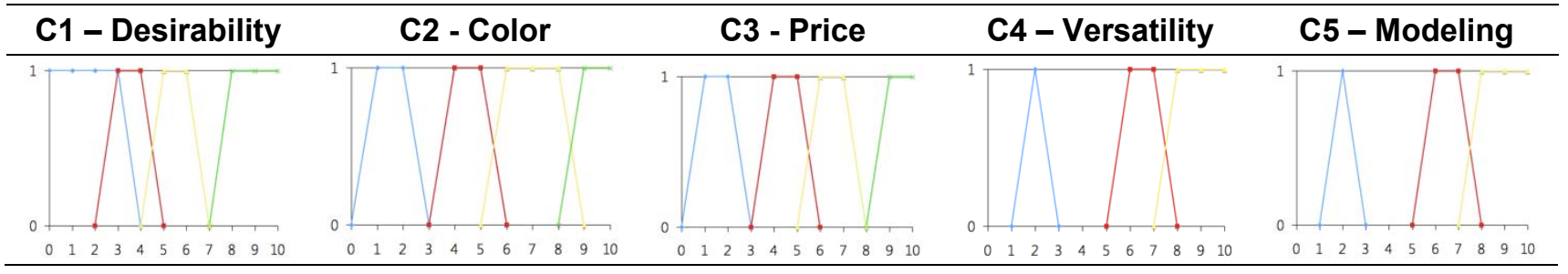

Table 4 - Three modifiers and fuzzy sets used in the Desire's Algorithm.

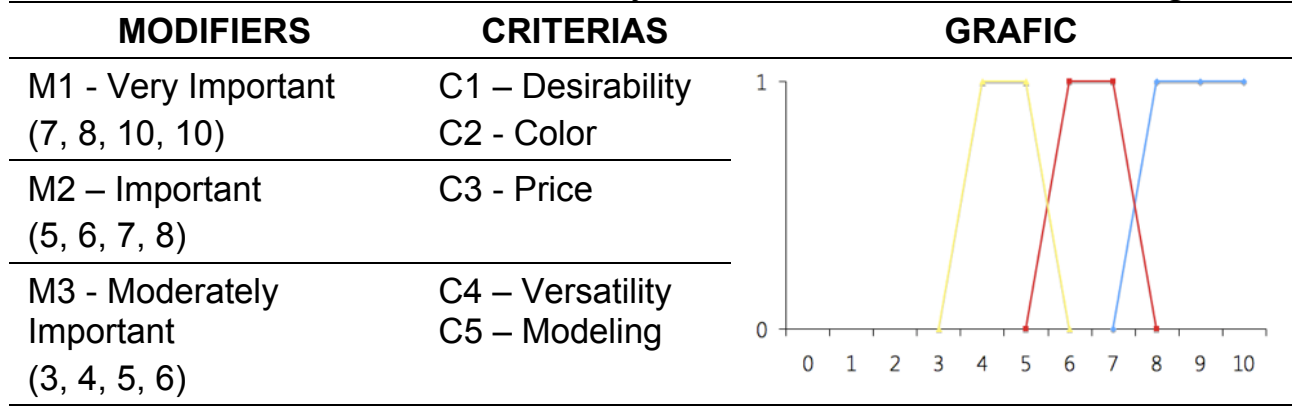

\subsection{Processing Data}

Step 1 - Apply the Modifier On Criteria for each response

$$
\begin{aligned}
& {[C 1(d, a, b, c) \otimes M 1(d, a, b, c)]=C 1^{\prime}(d, a, b, c)} \\
& {[C 2(d, a, b, c) \otimes M 1(d, a, b, c)]=C 2^{\prime}(d, a, b, c)} \\
& {[C 3(d, a, b, c) \otimes M 2(d, a, b, c)]=C 3^{\prime}(d, a, b, c)} \\
& {[C 4(d, a, b, c) \otimes M 3(d, a, b, c)]=C 4^{\prime}(d, a, b, c)} \\
& {[C 5(d, a, b, c) \otimes M 3(d, a, b, c)]=C 5^{\prime}(d, a, b, c)}
\end{aligned}
$$

Step 2 - Sum the Criteria to achieve the Fuzzy Rate

$$
\begin{gathered}
C 1^{\prime}(d, a, b, c) \oplus C 2^{\prime}(d, a, b, c) \oplus C 3^{\prime}(d, a, b, c) \oplus C 4^{\prime}(d, a, b, c) \oplus C 5^{\prime}(d, a, b, \\
c)=\text { Fuzzy Rate }(d, a, b, c)
\end{gathered}
$$

Step 3 - Sum the Fuzzy Rate Line 
INDEPENDENT JOURNAL OF MANAGEMENT \& PRODUCTION (IJM\&P)

http://www.ijmp.jor.br

v. 4, n. 1, January - June 2013.

ISSN: 2236-269X

DOI: 10.14807/iimp.v4i1.75

$$
d+a+b+c=\text { Attractiveness Index }
$$

Step 4 - Calculate all possible combination of Criteria and normalize results.

A list of 576 Attractiveness Index will be found as the result of crossing all response alternatives:

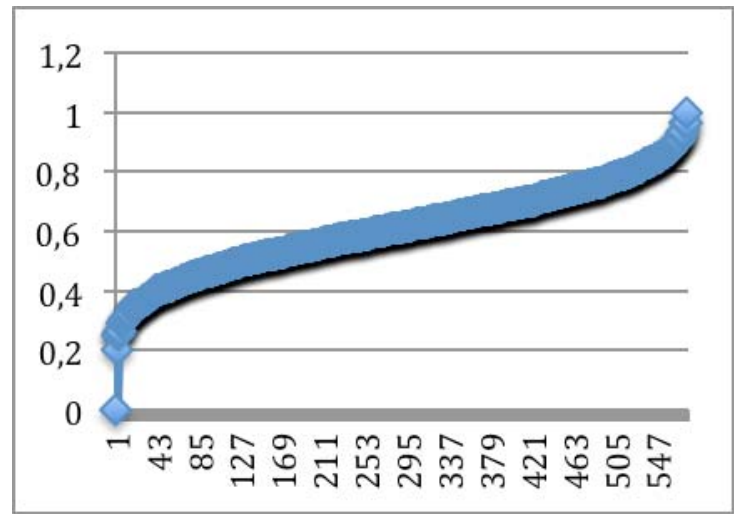

Figure 1 - Curve plotted by the 576 different possibilities of answers in product evaluation.

Table 5 - Desire's Algorithm - evaluation of price for the same product.

\begin{tabular}{|c|c|c|c|c|c|}
\hline \multicolumn{2}{|c|}{ STEPS } & PRODUCT 1 & PRODUCT 2 & PRODUCT 3 & PRODUCT 4 \\
\hline \multirow{5}{*}{$\begin{array}{c}\text { MODIFIED } \\
\text { CRITERIA } \\
\text { C (d, a, b, c) } \\
\otimes \\
\text { M (d, a, b, c) } \\
= \\
C^{\prime}(d, a, b, c)\end{array}$} & $\mathrm{C}^{\prime}(\mathrm{D}, \mathrm{A}, \mathrm{B}, \mathrm{C})$ & $\begin{array}{l}\text { VERY DESIRABLE } \\
(49,64,100,100)\end{array}$ & $\begin{array}{l}\text { VERY DESIRABLE } \\
(49,64,100,100)\end{array}$ & $\begin{array}{l}\text { VERY DESIRABLE } \\
(49,64,100,100)\end{array}$ & $\begin{array}{c}\text { VERY DESIRABLE } \\
(49,64,100,100)\end{array}$ \\
\hline & $C 2^{\prime}(\mathrm{D}, \mathrm{A}, \mathrm{B}, \mathrm{C})$ & $\begin{array}{c}\text { LIKE } \\
(35,48,80,90)\end{array}$ & $\begin{array}{c}\text { LIKE } \\
(35,48,80,90)\end{array}$ & $\begin{array}{c}\text { LIKE } \\
(35,48,80,90)\end{array}$ & $\begin{array}{c}\text { LIKE } \\
(35,48,80,90)\end{array}$ \\
\hline & $C 3^{\prime}(D, A, B, C)$ & $\begin{array}{c}\text { VERY EXPENSIVE } \\
(0,6,14,24)\end{array}$ & $\begin{array}{c}\text { EXPENSIVE } \\
(15,24,35,48)\end{array}$ & $\begin{array}{c}\text { COHERENT } \\
(25,36,49,64)\end{array}$ & $\begin{array}{c}\text { CHEAP } \\
(40,54,70,80)\end{array}$ \\
\hline & $\mathrm{C}^{\prime}(\mathrm{D}, \mathrm{A}, \mathrm{B}, \mathrm{C})$ & $\begin{array}{c}\text { VERSATILE } \\
(15,24,35,48)\end{array}$ & $\begin{array}{c}\text { VERSATILE } \\
(15,24,35,48)\end{array}$ & $\begin{array}{c}\text { VERSATILE } \\
(15,24,35,48)\end{array}$ & $\begin{array}{c}\text { VERSATILE } \\
(15,24,35,48)\end{array}$ \\
\hline & $\mathrm{C5}^{\prime}(\mathrm{D}, \mathrm{A}, \mathrm{B}, \mathrm{C})$ & $\begin{array}{c}\text { DO NOT DRESS } \\
\text { WELL } \\
(3,8,10,18) \\
\end{array}$ & $\begin{array}{c}\text { DO NOT DRESS } \\
\text { WELL } \\
(3,8,10,18) \\
\end{array}$ & $\begin{array}{c}\text { DO NOT DRESS } \\
\text { WELL } \\
(3,8,10,18) \\
\end{array}$ & $\begin{array}{c}\text { DO NOT DRESS } \\
\text { WELL } \\
(3,8,10,18) \\
\end{array}$ \\
\hline FUZZY SUM $\oplus$ & $\sum_{i=1}^{5} C^{\prime}(d, a, b, c)$ & $(102,150,225,280)$ & $(117,168,260,304)$ & $(127,180,274,320)$ & $(142,198,295,336)$ \\
\hline $\begin{array}{c}\text { ATTRACTIVENESS } \\
\text { INDEX }\end{array}$ & $(d+a+b+c)$ & 757 & 849 & 901 & 971 \\
\hline $\begin{array}{l}\text { ATTRACTIVENESS } \\
\text { INDEX / } 1211\end{array}$ & $\begin{array}{c}\text { FINAL RESULT } \\
\text { AFTER } \\
\text { NORMALIZE } \\
\end{array}$ & 0,62510 & 0,70107 & 0,74401 & 0,80182 \\
\hline
\end{tabular}

\subsection{Algorithm Outputs}

Now it's time to take decisions based on risk analysis. As outputs, the decisions options are listed in 4 categories divided by intervals:

Do Not Produce: Attractiveness Index - Less than 0,55 (194 results)

The algorithm considers that the product is not good enough to be manufactured. In other words, the product was rejected by the appraisers' opinion and represents a high-risk investment. It will increase losses in the product mix.

Low Attraction: Attractiveness Index - Between 0,55 and 0,65 (148 results) 
INDEPENDENT JOURNAL OF MANAGEMENT \& PRODUCTION (IJM\&P)

http://www.ijmp.jor.br

v. 4, n. 1, January - June 2013.

ISSN: 2236-269X

DOI: 10.14807/iimp.v4i1.75

The product can be manufactured but represents a high-risk investment. The premium-selling price will not be achieved, a large part of the lot will be sold in the clearance-selling and another part will end up in the storage.

The production managers shall take a look at the production cost and check if a price change would increase the product attraction.

Medium Attraction: Attractiveness Index - Between 0,65 and 0,75 (129 results)

The product will be well sold. This product will probably have a good premiumselling and a short quantity of products will be sold in a clearance-selling. These products are very important in the product mix and represent a medium risk investment with major probability of success.

High Attraction: Attractiveness Index - More than 0,75 (105 results)

The product is very well accepted in a premium-selling price and a residual part of the lot will be completely sold in the clearance-selling. These products are premium and represent the best manufacture option. It represents the minimum risk in investment portfolio.

\subsection{Analyzing Results}

As seen below, based on results exhibited in table 5 , the output can be analyzed for evaluation of attractiveness.

Observe that the price policies can be reviewed in this example. The medium attraction result appears in two products and the customer can accept the expensive price. The manager can take the decision to maintain the expensive price and exceed the markup margin and, in the clearance selling, change price from to the coherent, maintaining the attractiveness.

Table 6 - Desire's Algorithm - evaluation of attractiveness.

\begin{tabular}{ccccc}
\hline DESIRE'S ALGORITHM & PRODUCT 1 & PRODUCT 2 & PRODUCT 3 & PRODUCT 4 \\
\hline $\begin{array}{c}\text { FINAL RESULT } \\
\text { AFTER NORMALIZE }\end{array}$ & 0,62510 & 0,70107 & 0,74401 & 0,80182 \\
\hline OUT PUT & LOW & MEDIUM & MEDIUM & HIGH \\
& ATTRACTION & ATTRACTION & ATTRACTION & ATTRACTION \\
\hline
\end{tabular}


INDEPENDENT JOURNAL OF MANAGEMENT \& PRODUCTION (IJM\&P)

http://www.ijmp.jor.br

v. 4, n. 1, January - June 2013.

ISSN: 2236-269X

DOI: 10.14807/iimp.v4i1.75

\subsection{Expected Value in Bet}

Table 7 - Attractiveness output and respective sales probability.

\begin{tabular}{|c|c|c|c|c|c|c|c|}
\hline MARKUP & \multirow{2}{*}{\multicolumn{2}{|c|}{$\begin{array}{c}\text { PREMIUM } \\
2,5\end{array}$}} & \multirow{2}{*}{\multicolumn{2}{|c|}{$\begin{array}{c}\text { CLEARANCE } \\
1,8\end{array}$}} & \multirow{2}{*}{\multicolumn{2}{|c|}{$\begin{array}{c}\text { STOCK } \\
0,8\end{array}$}} & \multirow{3}{*}{$\begin{array}{c}\begin{array}{c}\text { EXPECTED } \\
\text { VALUE }\end{array} \\
\$ 1,10\end{array}$} \\
\hline OUTPUT & & & & & & & \\
\hline DO NOT PRODUCE & $0 \%$ & $\$ 0,00$ & $30 \%$ & $\$ 0,54$ & $70 \%$ & $\$ 0,56$ & \\
\hline LOW ATTRACTION & $20 \%$ & $\$ 0,50$ & $50 \%$ & $\$ 0,90$ & $30 \%$ & $\$ 0,24$ & $\$ 1,64$ \\
\hline MEDIUM ATTRACTION & $50 \%$ & $\$ 1,25$ & $40 \%$ & $\$ 0,72$ & $10 \%$ & $\$ 0,08$ & $\$ 2,05$ \\
\hline HIGH ATTRACTION & $80 \%$ & $\$ 2,00$ & $20 \%$ & $\$ 0,36$ & $0 \%$ & $\$ 0,00$ & $\$ 2,36$ \\
\hline
\end{tabular}

Table 7 presents the simulation of sales divided by the different output. As the attraction between customers and products grows the sales results increase the expected value. The premium price is achieved with more intensity in the high attraction group.

This model is experimental. It has been tested with great results for some brands in Brazil. More than a hundred products were evaluated and the algorithm results have helped the production managers to take their decisions in a more assertive way.

The old method to process the bet is a prediction about future sales based in the launch sales. The productions managers usually do the bet multiplying launch sales by two and half times.

\section{CONCLUSIONS}

The fuzzy model is more sensible to treat data and produces a straight approach to the customer's desire. It is a tool that helps the production managers to give a better look at the production prediction. It can anticipate the problems that cause losses and consequently reduce profit.

Observe that the best result in sale's probability achieves an average of 2,36 in markup. It is absolutely reasonable result.

As production manager, the selection of a good portfolio of products, represented by a successful collection, must be done based in profit possibilities. That is the main point that must be achieved.

\section{FINAL CONSIDERATIONS}

As final consideration, the fuzzy model called Desire's Algorithm is a tool that must be developed and the researches done until the moment show that crossing 
INDEPENDENT JOURNAL OF MANAGEMENT \& PRODUCTION (IJM\&P)

http://www.ijmp.jor.br

v. 4, n. 1, January - June 2013.

ISSN: 2236-269X

DOI: 10.14807/iimp.v4i1.75

GIS information with the algorithm results can be very important to the fashion business development.

The use of new interfaces based on applications made for tablets are being studied as a way to collect customer's opinions in fashion fair and events. The regional opinion can be collected in sales points and appraisers from many parts of the country can be added to generate a regional view of acceptance of determined product mix.

\section{REFERENCES}

ABRANCHES, G. P. (1990) Manual da gerência de confecção: a indústria de confecções de estrutura elementar - VOLUME I. Rio de Janeiro: SENAI-CETIQT: CNPQ : IBICT: PADCT: TIB.

BLACKWELL, R. D. (2005) Comportamento do consumidor. São Paulo: Pioneira Thomson Learning.

CHEN, Shan-Huo. (1985) Ranking Fuzzy Numbers with maximizing and minimizing set. Fuzzy Sets and Systems. North-Holland: Elsevier Science Publishers.

CHURCHILL, G. A. (2000) Marketing: Criando valor para o cliente. São Paulo: Saraiva.

CLEMENTE, A. (1998) Projetos Empresariais e Públicos. São Paulo: Atlas, 1998.

COSENZA, C. An Industrial Location Model, Working Paper, Martin Centre for Architectural and Urban Sites Studies, Cambridge University, Cambridge.

DORIA, F.; DORIA, P. (1999) Comunicação: dos fundamentos à internet. Rio de Janeiro: Renavan.

HASS, R.; MEIXNER, O.(2002) An illustrated Guide to the Analytic Hierarchy Process. Institute of Marketing and Innovation. http://www.boku.ac.at/mi/.

KOTLER, P. (1996) Administração de Marketing: análise, planejamento, implementação e controle. 4a ed. São Paulo: Atlas.

KOLTLER, P. (2005) O Marketing sem segredos: Philip Kotler responde as suas dúvidas. Porto Alegre: Bookman.

LIANG, Gin-Shuh. WANG, Mao-Jiun A fuzzy multi-criteria decision-making method for facility site selection. INT. J.

NARASIMHAN, R. (1979) A fuzzy subset characterization of a site selection problem. Decision Sciences, v. 10, n. 4p. 618-628.

NARASIMHAN, R. (1991) A fuzzy subset characterization of a site selection problem.

PROD. RES. V. 29, n. 11, p. 2313-2330.

PORTER, M. E. (2004) Estratégia Competitiva: técnicas para a análise de indústrias e da concorrência. $3^{a}$ re-impressão. Rio de Janeiro: Elsevier.

ROSS, T. J. (2010) Fuzzy Logic with engineering applications. $3^{\text {rd }}$ edition. UK: John Wiley and Sons Ltd. 
INDEPENDENT JOURNAL OF MANAGEMENT \& PRODUCTION (IJM\&P)

http://www.ijmp.jor.br

v. 4, n. 1, January - June 2013.

ISSN: 2236-269X

DOI: 10.14807/iimp.v4i1.75

SLACK, N. et al. (1997) Administração da Produção. São Paulo: Atlas.

TERANO, T. (1992) Fuzzy Systems Theory and Its Aplication. San Diego:

Academic Press. 